\author{
Jerzy Wyrzykowski \\ Uniwersytet Wrocławski \\ Zakład Geografii Regionalnej i Turystyki \\ 50-137 Wrocław, pl. Uniwersytecki 1 \\ tel. (071) 3752243 \\ wyrzykowski@geogr.uni.wroc.pl
}

\section{MIEJSCE BUEGARII NA RYNKU TURYSTYCZNYM EUROPY ŚRODKOWEJ I WSCHODNIEJ}

\section{WPROWADZENIE}

Europa Środkowa i Wschodnia stanowi jeden z regionów turystyki międzynarodowej, uwzględniony także w statystyce Światowej Organizacji Turystycznej. W niniejszym ujęciu, odbiegającym nieco od proponowanego przez WTO, w jego skład zaliczono 20 byłych socjalistycznych krajów europejskich, które zajmują 2/3 ogólnej powierzchni kontynentu. W okresie powojennym we wszystkich tych krajach, poza byłą Jugosławią, dominował model turystyki socjalnej, zaś turystyka krajowa stanowiła główną część ruchu turystycznego. Rozwój zagranicznej turystyki przyjazdowej, któremu większą uwagę, poza Jugosławią, poświęciły takie kraje, jak Węgry, dawna Czechosłowacja, Bułgaria, a także Rumunia, traktowany był głównie jako czynnik równoważący bilans dewizowy.

Zmiany polityczne, społeczne i gospodarcze przełomu lat 80. i 90. ubiegłego wieku, wprowadzenie zasad gospodarki rynkowej do gospodarki turystycznej, rozpad Związku Radzieckiego, Czechosłowacji i dawnej Jugosławii, zmieniły w sposób zasadniczy podejście do rozwoju turystyki, w tym zagranicznej turystyki przyjazdowej. Większość krajów uznała, że turystyka stanowić powinna ważny dział gospodarki narodowej i podjęła działania na rzecz dostosowania gospodarki turystycznej do wymagań rynkowych. Wyraża się to m.in. większą troską o walory przyrodnicze i kulturowe, o objęcie ich ochroną prawną i przystosowaniem dla turystyki, promocją atrakcji turystycznych i wprowadzaniem ich do światowych katalo-

\section{BULGARIA ON THE CENTRAL AND EASTERN EUROPE TOURISM MARKET}

\section{INTRODUCTION}

Central and Eastern Europe is an international tourism region included in the statistics of the World Tourism Organization and in this article it is assumed that it consists of the 20 former socialist countries which take up two thirds of the overall continental area. In the post-war period in all these countries, except Yugoslavia, social tourism (mostly national) was dominant. The development of inward foreign tourism, treated seriously in Yugoslavia, Hungary, Czechoslovakia, Bulgaria and Romania, was seen mainly as a foreign exchange balancing factor.

The political, social and economic changes at the turn of the 1990s which introduced the market economy into tourism, and the dissolution of the Soviet Union, Czechoslovakia and Yugoslavia, altered considerably attitudes to the development of tourism including inward foreign tourism. The majority of countries decided that tourism should be an important sector of the national economy and took steps towards adjusting the tourism economy to market requirements. This showed in an increased care for natural and cultural assets, in giving them legal protection and adapting them for tourism, in the promotion of tourism attractions and their presence on world lists of tourism sites, restructuring the tourism infrastructure in 
gów turystycznych, restrukturyzacja bazy turystycznej w celu podniesienia jej standardu i dostosowania do potrzeb turystyki komercyjnej.

W pierwszym okresie, do przelomu lat 80, i 90. ubiegłego wieku, Bułgaria stała się ważnym celem turystyki międzynarodowej, przede wszystkim turystów z kraju obozu socjalistycznego. W drugiej połowie lat 80 . liczba odwiedzających z zagranicy wzrosła do $10 \mathrm{mln}$, liczba turystów do $4,5 \mathrm{mln}$ osób, zaś liczba noclegów udzielonych turystom zagranicznym osiągnęla $20 \mathrm{mln}$ (WYRZYKOWSKI 1995). Ponad $80 \%$ noclegów wykorzystywali turyści z krajów socjalistycznych (BACHVAROV 2006). $\mathrm{Na}$ wydatki na turystykę zagraniczną własnych obywateli Bułgaria przeznaczała w tym okresie od kilkudziesięciu do ponad $100 \mathrm{mln}$ USD rocznie.

Po zmianach polityczno-społecznych i gospodarczych $w$ regionie w latach 90 . liczba przyjeżdżających do Bułgarii zdecydowanie zmalała. Prawie zupehnie zrezygnowali z przyjazdów mieszkańcy dawnych krajów socjalistycznych, a także krajów sąsiednich - Turcji i Grecji. Na w miarę stabilnym poziomie utrzymały się przyjazdy z krajów Unii Europejskiej, w szczególności Niemców i Anglików (BACHVAROV 2006). Wydatki na wyjazdy zagraniczne Bułgarów znacznie się obniżyły. Ponowny wzrost wielkości zagranicznej turystyki przyjazdowej do Bułgarii i wyjazdów zagranicznych Bułgarów odnotowuje się od końca lat 90.

\section{POTENCJAL TURYSTYCZNY BUEGARII NA TLE INNYCH PAŃSTW EUROPY ŚRODKOWEJ I WSCHODNIEJ}

Największą powierzchnią i liczbą ludności dysponują Rosja, Ukraina i Polska. Bułgaria zajmuje piątą pozycję pod względem powierzchni i siódmą pod względem liczby ludności. Produkt krajowy brutto w przeliczeniu na 1 mieszkańca jest najwyższy w Słowenii, Polsce, Czechach i na Węgrzech. Bułgaria zajmuje 12 . pozycję, ze stosunkowo skromnym wskaźnikiem 3,3 tys. USD na 1 mieszkańca (tab. I).

Potencjał turystyczny poszczególnych krajów Europy Środkowej i Wschodniej wyrazić można m.in. liczbą parków narodowych, liczbą obiektów wpisanych na listę dziedzictwa światowego UNESCO oraz liczbą atrakcji turystycznych ujętych na mapie „International tourism attractions in Central and South-Eastern Europe" (1998). order to raise its standard and adapting it to the needs of commercial tourism.

In the first period, until this turn, Bulgaria had become an important international tourism destination, mainly for tourists from the socialist bloc. In the second half of the 1980s the numbers crossing the border rose to $10 \mathrm{mln}$, the number of tourists to $4.5 \mathrm{mln}$, and the number of beds sold to foreign tourists reached $20 \mathrm{mln}$ (WYRZYKOWSKI 1995). Over $80 \%$ of the beds were used by tourists from socialist countries (BACHVAROV 2006). At that time foreign tourism by Bulgarian citizens cost the country up to $100 \mathrm{mln}$ and more US dollars annually.

In the 1990s after the political, social and economic changes had taken place, the number of visitors coming to Bulgaria visibly decreased and the citizens of former socialist countries, as well as neighbouring Turkey and Greece, stopped coming almost completely. Arrivals from European Union countries, especially from Germany and Great Britain, remained relatively stable (BACHVAROV 2006) but the amount of money Bulgarians spent on travelling abroad considerably decreased. An increase in inward foreign tourism and in Bulgarian outward tourism was noted from the late 1990s onwards.

\section{THE TOURISM POTENTIAL OF BULGARIA CONTRASTED WITH OTHER CENTRAL AND EASTERN EUROPE COUNTRIES}

The countries with the largest areas and populations are Russia, Ukraine and Poland, while Bulgaria comes fifth as regards area and seventh for population. The gross national product per citizen is highest in Slovenia, Poland, the Czech Republic and Hungary, while Bulgaria is $12^{\text {th }}$ with 3,300 US dollars per citizen (table I).

The tourism potential of individual countries in Central and Eastern Europe can be expressed by the number of national parks, UNESCO world heritage list sites and the attractions on the map entitled International tourism attractions in Central and South-Eastern Europe (1998). 
T a b e I a I. Ogólna charakterystyka krajów Europy Srodkowej i Wschodniej

\begin{tabular}{|l|r|r|r|c|}
\hline \multicolumn{1}{|c|}{ Nazwa kraju } & $\begin{array}{r}\text { Powierzchnia } \\
(\text { (w tys. km²) }\end{array}$ & $\begin{array}{r}\text { Ludność } \\
\text { (w mln) }\end{array}$ & $\begin{array}{r}\text { PKB/1 } \\
\text { mieszkanca } \\
\text { (w USD) }\end{array}$ & $\begin{array}{c}\text { Cztonko- } \\
\text { stwo w UE }\end{array}$ \\
\hline Albania & 28,7 & 3,1 & 2461 & nie \\
\hline Białoruśs & 207,6 & 9,8 & 2775 & nie \\
\hline Bośnia i Hercegowina & 51,2 & 3,5 & 2423 & nie \\
\hline Bułgaria & 111,0 & 7,8 & 3328 & tak \\
\hline Chorwacja & 56,6 & 4,5 & 8345 & nie \\
\hline Czarnogóra & 13,8 & 0,6 & 2113 & nie \\
\hline Czechy & 78,9 & 10,2 & 12106 & tak \\
\hline Estonia & 45,2 & 1,3 & 9727 & tak \\
\hline Litwa & 65,3 & 3,4 & 7511 & tak \\
\hline Lotwa & 64,6 & 2,3 & 7193 & tak \\
\hline Macedonia & 25,7 & 2,0 & 2431 & nie \\
\hline Mołdawia & 33,8 & 4,0 & 825 & nie \\
\hline Polska & 312,7 & 38,2 & 13300 & tak \\
\hline Rosja (Fed. Rosyjska) & 17075,4 & 143,5 & 5369 & nie \\
\hline Rumunia & 238,4 & 21,6 & 4539 & tak \\
\hline Serbia & 88,4 & 10,0 & 3139 & nie \\
\hline Stowacja & 49,0 & 5,4 & 8647 & tak \\
\hline Słowenia & 20,3 & 2,0 & 17066 & tak \\
\hline Ukraina & 603,7 & 46,7 & 1727 & nie \\
\hline Węgry & 93,0 & 10,1 & 11217 & tak \\
\hline
\end{tabular}

Ż ródło: Encyklopedia..., 2007.

T a b e I a II. Zestawienie ilościowe parków narodowych i obiektów dziedzictwa światowego UNESCO w krajach Europy Środkowej i Wschodniej

\begin{tabular}{|l|c|c|}
\hline \multicolumn{1}{|c|}{ Nazwa kraju } & $\begin{array}{c}\text { Liczba parków } \\
\text { narodowych }\end{array}$ & $\begin{array}{c}\text { Liczba obiektów } \\
\text { dziedzictwa } \\
\text { swiatowego UNESCO }\end{array}$ \\
\hline Albania & 12 & 2 \\
\hline Białorus & 4 & 4 \\
\hline Bośnia i Hercegowina & 2 & 1 \\
\hline Bułgaria & 3 & 9 \\
\hline Chorwacja & 8 & 6 \\
\hline Czarnogóra & 4 & 2 \\
\hline Czechy & 4 & 12 \\
\hline Estonia & 5 & 2 \\
\hline Litwa & 5 & 4 \\
\hline Lotwa & 5 & 2 \\
\hline Macedonia & 2 & 1 \\
\hline Mołdawia & - & 1 \\
\hline Polska & 23 & 13 \\
\hline Rosja & 4 & 22 \\
\hline Rumunia & 11 & 7 \\
\hline Serbia & 5 & 3 \\
\hline Słowacja & 9 & 5 \\
\hline Słowenia & 1 & 1 \\
\hline Ukraina & 11 & 3 \\
\hline Węgry & 10 & 8 \\
\hline Ogółem & 128 & 108 \\
\hline
\end{tabular}

'Rosja z częścią azjatycką.

Ż r ó d ł o: http://en.wikipedia.org/wiki/list of national parks i inne strony internetowe(dla Albanii, Bułgarii i Ukrainy).

Łączna liczba parków narodowych w Europie Środkowej i Wschodniej wynosi obecnie 128. Największą liczbę parków narodowych utworzono do
T a b e I a I. Ogólna charakterystyka krajów Europy Środkowej iWschodniej

\begin{tabular}{|l|r|r|r|c|}
\hline \multicolumn{1}{|c|}{ Nazwa kraju } & $\begin{array}{r}\text { Powierzchnia } \\
(\text { (w tys. km²) }\end{array}$ & $\begin{array}{r}\text { Ludność } \\
\text { (w mln) }\end{array}$ & $\begin{array}{r}\text { PKB/1 } \\
\text { mieszkanca } \\
\text { (w USD) }\end{array}$ & $\begin{array}{c}\text { Członko- } \\
\text { stwo w UE }\end{array}$ \\
\hline Albania & 28,7 & 3,1 & 2461 & nie \\
\hline Białoruśs & 207,6 & 9,8 & 2775 & nie \\
\hline Bośnia i Hercegowina & 51,2 & 3,5 & 2423 & nie \\
\hline Bułgaria & 111,0 & 7,8 & 3328 & tak \\
\hline Chorwacja & 56,6 & 4,5 & 8345 & nie \\
\hline Czarnogóra & 13,8 & 0,6 & 2113 & nie \\
\hline Czechy & 78,9 & 10,2 & 12106 & tak \\
\hline Estonia & 45,2 & 1,3 & 9727 & tak \\
\hline Litwa & 65,3 & 3,4 & 7511 & tak \\
\hline Łotwa & 64,6 & 2,3 & 7193 & tak \\
\hline Macedonia & 25,7 & 2,0 & 2431 & nie \\
\hline Mołdawia & 33,8 & 4,0 & 825 & nie \\
\hline Polska & 312,7 & 38,2 & 13300 & tak \\
\hline Rosja (Fed. Rosyjska) & 17075,4 & 143,5 & 5369 & nie \\
\hline Rumunia & 238,4 & 21,6 & 4539 & tak \\
\hline Serbia & 88,4 & 10,0 & 3139 & nie \\
\hline Słowacja & 49,0 & 5,4 & 8647 & tak \\
\hline Słowenia & 20,3 & 2,0 & 17066 & tak \\
\hline Ukraina & 603,7 & 46,7 & 1727 & nie \\
\hline Wegry & 93,0 & 10,1 & 11217 & tak \\
\hline
\end{tabular}

Żród ło: Encyklopedia..., 2007.

T a b I e II. National parks and UNESCO world heritage sites in the countries of Central and Eastern Europe

\begin{tabular}{|l|c|c|}
\hline \multicolumn{1}{|c|}{ Country } & $\begin{array}{c}\text { No of national } \\
\text { parks }\end{array}$ & $\begin{array}{c}\text { No of UNESCO world } \\
\text { heritage sites }\end{array}$ \\
\hline Albania & 12 & 2 \\
\hline Belarus & 4 & 4 \\
\hline Bosnia \& Herzegovina & 2 & 1 \\
\hline Bulgaria & 3 & 9 \\
\hline Croatia & 8 & 6 \\
\hline Czech Republic & 4 & 12 \\
\hline Estonia & 5 & 2 \\
\hline Hungary & 10 & 8 \\
\hline Latvia & 5 & 4 \\
\hline Lithuania & 5 & 2 \\
\hline Macedonia & 2 & 1 \\
\hline Moldavia & - & 1 \\
\hline Montenegro & 4 & 2 \\
\hline Poland & 23 & 13 \\
\hline Romania & 11 & 7 \\
\hline Russia & 4 & 221 \\
\hline Serbia & 5 & 3 \\
\hline Slovakia & 9 & 5 \\
\hline Slovenia & 1 & 1 \\
\hline Ukraine & 11 & 3 \\
\hline Total & 128 & 108 \\
\hline
\end{tabular}

1 Russia including the Asiatic part

S o u r ce: http://en.wikipedia.org/wiki/list for national parks and other websites (for Albania, Bulgaria and Ukraine)

The current overall number of national parks in Central and Eastern Europe is 128 with the largest number in Poland, 
tej pory w Polsce, Albanii, Rumunii i na Ukrainie, żadnego parku nie posiada jeszcze Mołdawia. Bułgaria ma trzy parki narodowe, a ponadto dziewięć parków natury. Zauważyć należy, że informacje internetowe podają bardzo różne liczby parków w poszczególnych krajach, a oficjalna internetowa lista IUCN pochodzi sprzed kilkunastu lat. Parkami narodowymi Bułgarii są: Centralny Bałkański Park Narodowy, Park Narodowy Pirinu i Park Narodowy Riła. Położona w pobliżu Sofii Witosza ma status parku natury (tab. II).

Łączna liczba obiektów dziedzictwa kulturowego i naturalnego UNESCO wynosi 108 (tab. II). Największą liczbę obiektów posiadają Rosja (z częścią azjatycka), Czechy i Polska. Bulgaria zajmuje pod tym względem czwarte miejsce $\mathrm{w}$ regionie. Status obiektu dziedzictwa światowego posiadają: Cerkiew Bojańska k. Sofii, Jeździec Tracki z Madary, zespół cerkwi wykutych w skale w Iwanowie, Grobowiec Tracki z Kazanłyku, zabytkowe miasto Nesebyr, rezerwat przyrody Srebyrna, Park Narodowy Pirinu, Monastyr Rilski i Grobowiec Tracki w Swesztari.

Mapa „International tourism attractions in Central and South-Eastern Europe" została opracowana przez międzynarodowy zespół badawczy pod kierunkiem JORDANA i in. (1999). Na obszarze zbliżonym do Europy Środkowej i Wschodniej, do kategorii ,atrakcje światowe” zaliczono Prage (Czechy) i deltę Dunaju (Rumunia), do kategorii „europejskie atrakcje” - 24 miejsca, do kategorii „ważne atrakcje międzynarodowe" - 346 i do innych międzynarodowych atrakcji - 1033 miejsca. Mapa zaadresowana była m.in. do potencjalnych inwestorów w zakresie przemysłu turystycznego. Największa liczba atrakcji związana jest z Polska, Rumunią i Czechami. Bułgarii przypisano dwie „europejskie atrakcje” (Rilski Manastir, Veliko Tarnovo), 33 ,ważne atrakcje międzynarodowe” (Aladža, Aleko, Arbanasi, Bačkovo, Bojana, Borovec, Centralny Bałkan, Čudnite Mostowe, Devetaška Peštera, Haskovo, Hisarja, Ivanovo, Kasanlăk, Koprivštica, Madara, Mezek, Nesebâr, Pamporovo, Pliska, Plovdiv, Pobiti Kamani, Pomorie, Razgrad, Rila, Ropotamo, Sapareva Banja, Sinite Kamani, Snežanka, Sofija, Sozopol, Sweštari, Trojan, Varna) i 76 z kategorii ,inne atrakcje międzynarodowe" (tab. III).

Potencjał walorów turystycznych Bułgarii stawia ją w grupie kilku najbardziej atrakcyjnych krajów Europy Środkowej i Wschodniej. W turystyce międzynarodowej szczególnie mocno należy pod-
Albania, Romania and Ukraine while Moldavia does has none. In Bulgaria there are three such parks and nine 'nature parks'. It should be noted that data from the internet quotes a differing figures for individual countries while the official IUCN internet list dates from several years back. The national parks in Bulgaria are Central Balkan, Pirin and Rila while Vitosha Mountain near Sofia has the status of a 'nature park' (table II).

The overall number of cultural and natural heritage sites placed on the UNESCO list in the region is 108 (table II) of which the largest number are found in Russia (including the Asiatic part), the Czech Republic and Poland. Bulgaria comes fourth in this respect including the following: Boyana Orthodox Church near Sofia, the Thracian Rider from Madara, a complex of Orthodox churches cut in the rock in Ivanovo, the Thracian Tomb from Kazanlak, the historical town of Nesebar, the Srebarna nature reserve, Pirin National Park, Rila Monastery and the Thracian Tomb in Sveshtari.

The International tourism attractions in Central and South-Eastern Europe map was prepared by an international research team supervised by Jordan (1999) and addressed at potential investors in the tourism industry. In the category 'World attractions' were Prague (the Czech Republic) and the Danube Delta (Romania), there were 24 in the category 'European attractions', 346 in the category 'Important international attrac-tions' and 1033 in the category 'Other international attractions'. The largest number occur in Poland, Romania and the Czech Republic. Bulgaria possesses two 'European attractions' (Rila Monastery, Veliko Turnovo), 33 'Important international attractions' (Ala-džha, Aleko, Arbanasi, Bačkovo, Boyana, Borovets, Central Balkan, Čudnite mostove, Devetaška Peštera, Haskovo, Hisarya, Ivanovo, Kasanlak, Koprivshtitsa, Madara, Mezek, Nesebâr, Pamporovo, Pliska, Plovdiv, Pobiti kamani, Pomorie, Razgrad, Rila, Ropotamo, Sapareva banya, Sinite kamani, Snežanka, Sofia, Sozopol, Sweštari, Troyan, Varna) and 76 'Other international attracions' (table III).

The potential of Bulgaria's tourism attractions is one of the greatest in Central and Eastern Europe while in international 
T a b e I I III. Potencjał turystyczny Europy Srodkowej i Wschodniej w świetle opracowania Austriackiego Instytutu Europy Srodkowej i Południowo-Wschodniej

\begin{tabular}{|l|c|c|c|c|}
\hline \multirow{2}{*}{ Kraj } & \multicolumn{4}{|c|}{ Liczba atrakcji międzynarodowych } \\
\cline { 2 - 5 } & $\begin{array}{c}\text { kategorii } \\
\text { I }\end{array}$ & $\begin{array}{c}\text { kategorii } \\
\text { II }\end{array}$ & $\begin{array}{c}\text { kategorii } \\
\text { III }\end{array}$ & $\begin{array}{c}\text { kategorii } \\
\text { IV }\end{array}$ \\
\hline Albania & - & - & 9 & 28 \\
\hline Białoruś & - & 1 & 8 & 38 \\
\hline Bośnia iHercegowina & - & 1 & 10 & 25 \\
\hline Bułgaria & - & 2 & 33 & 76 \\
\hline Chorwacja & - & 2 & 16 & 59 \\
\hline Czarnogóra & - & - & 14 & 22 \\
\hline Czechy & 1 & 2 & 25 & 115 \\
\hline Estonia' & & & & \\
\hline Litwa ${ }^{2}$ & - & 1 & 5 & 11 \\
\hline Lotwa' & & & & \\
\hline Macedonia & - & - & 8 & 29 \\
\hline Mołdawia & - & - & 6 & 23 \\
\hline Polska & - & 7 & 83 & 162 \\
\hline Rosja' & & & & \\
\hline Rumunia & 1 & 1 & 42 & 129 \\
\hline Serbia & - & - & 18 & 62 \\
\hline Słowacja & - & 1 & 23 & 47 \\
\hline Słowenia & - & 2 & 7 & 27 \\
\hline Ukraina ${ }^{2}$ & - & 2 & 15 & 117 \\
\hline Węgry & - & 2 & 25 & 64 \\
\hline Ogółem & 2 & 24 & 347 & 1033 \\
\hline
\end{tabular}

${ }^{1}$ Kraje nieujęte na mapie, ${ }^{2}$ kraje ujęte tylko częściowo.

Ż ró d ło: International... 1999.

kreślić walory wypoczynkowe wybrzeża czarnomorskiego. W opracowanej na początku lat 90 . ubiegłego wieku liście 10 . najbardziej popularnych miejscowości wypoczynkowych tej części Europy (PIETRASZEWSKA, WYRZYKOWSKI 1993) znalazły się trzy kapieliska czarnomorskie Bułgarii: Zlatni Pjasâci, Slâncěv Briag i Družba.

\section{STAN ZAGRANICZNEJ TURYSTYKI PRZYJAZDOWEJ DO BULGARII NA TLE INNYCH KRAJÓW REGIONU}

W 2004 r. najwięcej cudzoziemców przyjechało do Czech, Polski i na Węgry. Wprawdzie brak jest danych dla Chorwacji, ale biorąc pod uwage inne wskaźniki, spodziewać się można, że liczba przyjeżdżających cudzoziemców była tam również bardzo duża (tab. IV). Liczba odwiedzających Bułgarię, pomimo tendencji wzrostowych (2000 r. 3,5 mln osób, 2001 - 5,1 $\mathrm{mln}, 2002$ - 5,6 mln, $2003-6,2 \mathrm{mln}$ ), była kilkakrotnie niższa niż w tych krajach. Znacznie korzystniej wypada natomiast porównanie szacunkowej liczby turystów oraz liczby udzielonych noclegów turystom zagranicznym. Pod tym względem Bułgaria zaj-
T a b le III. Tourism potential of Central and Eastern Europe based on research by the Austrian Institute of Central and South-Eastern Europe

\begin{tabular}{|l|c|c|c|c|}
\hline \multirow{2}{*}{\multicolumn{1}{c|}{ Country }} & \multicolumn{4}{c|}{ No of international attractions } \\
\cline { 2 - 5 } & Cat.I & Cat. II & Cat. III & Cat. IV \\
\hline Albania & - & - & 9 & 28 \\
\hline Belarus & - & 1 & 8 & 38 \\
\hline Bosnia\& Herzegovina & - & 1 & 10 & 25 \\
\hline Bulgaria & - & 2 & 33 & 76 \\
\hline Croatia & - & 2 & 16 & 59 \\
\hline Czech Republic & 1 & 2 & 25 & 115 \\
\hline Estonia ${ }^{2}$ & & & & \\
\hline Hungary & - & 2 & 25 & 64 \\
\hline Latvia 1 & & & & \\
\hline Lithuania & & & & 11 \\
\hline Macedonia & - & 1 & 5 & 29 \\
\hline Moldavia & - & - & 8 & 23 \\
\hline Montenegro & - & - & 6 & 22 \\
\hline Poland & - & - & 14 & 162 \\
\hline Romania & - & 7 & 83 & 129 \\
\hline Russia ${ }^{1}$ & 1 & 1 & 42 & \\
\hline Serbia & & & & \\
\hline Slovakia & - & - & 18 & 62 \\
\hline Slovenia & - & 1 & 23 & 47 \\
\hline Ukraine ${ }^{2}$ & - & 2 & 7 & 27 \\
\hline Total & - & 2 & 15 & 117 \\
\hline
\end{tabular}

' Countries not found on the map. ${ }^{2}$ Countries found only in part.

So u r c e: International... 1999.

tourism the recreational assets of the Black Sea coast should particularly be emphasized. On the list of ten most popular recreational destinations in this part of Europe, compiled in the early 1990s (PIETRASZEWSKA \& WYRZYKOWSKI 1993), there are three Bulgarian Black Sea resorts: Zlatni Pjasâci, Slâncěv Bryag and Družba.

\section{FOREIGN TOURISM IN BULGARIA CONTRASTED WITH OTHER COUNTRIES IN THE REGION}

In 2004 the majority of inward foreign tourists went to the Czech Republic, Poland, and Hungary. There is no data regarding Croatia, but considering other indicators it can be expected that the number was also very high there (table IV). The number of visitors to Bulgaria, despite its tendency to grow (2000 - $3.5 \mathrm{mln}, 2001$ - $5.1 \mathrm{mln}$, $2002-5.6 \mathrm{mln}, 2003-6.2 \mathrm{mln}$ ), was several times smaller than those countries mentioned above. On the other hand, a comparison of the estimated number of tourists and the number of nights spent 
muje miejsce w pierwszej piątce krajów regionu, z liczbą 4,6 mln turystów i 9,1 mln udzielonych noclegów. Oznacza to, że zagraniczna turystyka przyjazdowa do Bułgarii wyrażona szacunkową liczbą turystów osiągnęła poziom z lat 80 . ubiegłego wieku, choć liczba odwiedzających i liczba noclegów udzielonych turystom zagranicznym jest jeszcze na poziomie połowy wielkości z tamtych lat.

T a b e I a IV. Stan turystyki zagranicznej w krajach Europy Środkowej i Wschodniej w 2004 r.

\begin{tabular}{|l|r|c|c|c|}
\hline \multicolumn{1}{|c|}{ Kraj } & $\begin{array}{c}\text { Odwiedza- } \\
\text { jacy (w tys. } \\
\text { osób) }\end{array}$ & $\begin{array}{c}\text { Turyści } \\
\text { (w tys. } \\
\text { osób) }\end{array}$ & $\begin{array}{c}\text { Korzysta- } \\
\text { jacy z bazy } \\
\text { noclegowej } \\
\text { (w tys.) }\end{array}$ & $\begin{array}{c}\text { Udzielone } \\
\text { noclegi } \\
\text { (w tys.) }\end{array}$ \\
\hline Albania & 645,4 & & & \\
\hline Białoruśs & 44,0 & & & \\
\hline Bośnia iHercegowina & & & 190,3 & \\
\hline Bułgaria & 6981,6 & 4630 & & $9142,2^{1}$ \\
\hline Chorwacja & & 7912 & & 42516,3 \\
\hline Czarnogóra & & & & \\
\hline Czechy & 95897,7 & 6061 & & 19980,5 \\
\hline Estonia & $3377,8^{1}$ & 1750 & & 1374,4 \\
\hline Litwa & 3635,3 & 1800 & 590,0 & 1113,1 \\
\hline Lotwa & 3033,4 & 1080 & 545,4 & 1200,6 \\
\hline Macedonia & & & 165,3 & 360,6 \\
\hline Mołdawia & & & & \\
\hline Polska & 61917,8 & 14290 & 3934,1 & 9312,9 \\
\hline Rosja ${ }^{2}$ & 22064,2 & & & \\
\hline Rumunia & 6600,1 & & 1359,5 & 3210,6 \\
\hline Serbia & & $580^{3}$ & $579,9^{3}$ & $1714,9^{3}$ \\
\hline Stowacja & & 1401 & 1401,2 & 4675,0 \\
\hline Stowenia & & 1499 & 1498,8 & 4362,8 \\
\hline Ukraina & $12513,9^{1}$ & $15629(?)$ & & \\
\hline Węgry & $31412,5^{1}$ & 12212 & 3269,9 & 10508,1 \\
\hline
\end{tabular}

1 Dane z 2003 r., ${ }^{2}$ dane dla całej Federacji Rosyjskiej, ${ }^{3}$ łacznie z Czarnogórą.

Ż r ó d ł o: Yearbook... 2006; " szacunek liczby turystów za: BARTOSZEWICZ i SKALSKA, 2006, powołujących się na UNWTO.

Wśród narodowości odwiedzających Bułgarię dominują: Macedończycy, Serbowie (z Czarnogórcami), Grecy, Turcy, Niemcy i Rumuni. Stanowią oni $2 / 3$ ogólnej liczby odwiedzających (tab. V).

Inaczej wygląda struktura narodowościowa turystów zagranicznych w Bułgarii pod względem liczby udzielonych im noclegów w 2003 r. Blisko połowa $(45,6 \%)$ noclegów przypada na Niemców, dalsze 11,5\% na Anglików i 7,8\% na Rosjan (tab. VI). Poza tym znaczniejszy udział w wykorzystaniu noclegów mają jeszcze Szwedzi, Finowie, Izraelici, Belgowie i Duńczycy. by them appears more positive. In this respect Bulgaria is in the top five countries of the region with $4.6 \mathrm{mln}$ tourists and 9.1 mln nights. This means that foreign inward tourists to Bulgaria (expressed by the estimated number of tourists) has reached the level recorded in the 1980s, although the number of visitors and the number of nights spent by foreign tourists is still half the number of that period.

$\mathrm{T}$ a b I e IV. Foreign tourism in the countries of Central and Eastern Europe in 2004

\begin{tabular}{|l|r|r|r|r|}
\hline \multicolumn{1}{|c|}{ Country } & $\begin{array}{r}\text { No } \\
\text { crossing } \\
\text { borders } \\
\text { ('000s) }\end{array}$ & $\begin{array}{c}\text { No of } \\
\text { tourists } \\
\text { ('000s) }\end{array}$ & $\begin{array}{c}\text { No of hotel } \\
\text { guests } \\
\text { ('000s) }\end{array}$ & $\begin{array}{c}\text { No of beds } \\
\text { sold }\end{array}$ \\
\hline Albania & 645.4 & & & \\
\hline Belarus & 44.0 & & & \\
\hline Bosnia\& Herzegovina & & & 190.3 & $9142.2^{1}$ \\
\hline Bulgaria & 6981.6 & 4630 & & 42516.3 \\
\hline Croatia & 95897.7 & 6061 & & 19980.5 \\
\hline Czech Republic & $3377.8^{1}$ & 1750 & & 1374.4 \\
\hline Estonia & $31412.5^{1}$ & 12212 & 3269.9 & 10508.1 \\
\hline Hungary & 3635.3 & 1800 & 590.0 & 1113.1 \\
\hline Latvia & 3033.4 & 1080 & 545.4 & 1200.6 \\
\hline Lithuania & & & 165.3 & 360.6 \\
\hline Macedonia & & & & \\
\hline Moldavia & & & & \\
\hline Montenegro & 61917.8 & 14290 & 3934.1 & 9312.9 \\
\hline Poland & 6600.1 & & 1359.5 & 3210.6 \\
\hline Romania & 22064.2 & & & \\
\hline Russia ${ }^{2}$ & $12513.9^{1}$ & $15629(?)$ & & $1714.9^{3}$ \\
\hline Serbia & $580^{3}$ & $579.9^{3}$ & 4675.0 \\
\hline Slovakia & 1401 & 1401.2 & 462.8 \\
\hline Slovenia & & & 1498.8 & 4369 \\
\hline Ukraine & & & & \\
\hline
\end{tabular}

1 Data from 2003; ${ }^{2}$ data for all of the Russian Federation; ${ }^{3}$ including Montenegro.

S o u r c e: Yearbook... 2006; * - estimated number of tourists from BARTOSZEWICZ \& SKALSKA, 2006 based on UNWTO.

The nationalities most frequently visiting Bulgaria are: Macedonians, Serbs (including tourists from Montenegro), Greeks, Turks, Germans and Romanians which together constitute two thirds of the overall number of visitors (table $\mathrm{V}$ ).

The nationality structure of foreign tourists in Bulgaria in 2003 differs as regards the number of nights spent. Nearly half $(45.6 \%)$ of the overall number are German, a further $11.5 \%$ - British and $7.8 \%$ - Russians (table VI). Figures for Swedes, Finns, Israelis, Belgians and Danes are also significant. 
T a b e l a V. Ważniejsze narodowości cudzoziemców odwiedzających Bułgarię w $2004 \mathrm{r}$.

\begin{tabular}{|l|c|c|}
\hline \multicolumn{1}{|c|}{ Kraj } & $\begin{array}{c}\text { Odwiedzający } \\
\text { (w tys.) }\end{array}$ & $\begin{array}{c}\text { \% ogółu } \\
\text { odwiedzajacych }\end{array}$ \\
\hline Macedonia & 857,9 & 12,3 \\
\hline Serbia z Czarnogóra & 853,1 & 12,2 \\
\hline Grecja & 803,3 & 11,5 \\
\hline Turcja & 760,9 & 10,9 \\
\hline Niemcy & 719,8 & 10,3 \\
\hline Rumunia & 612,6 & 8,8 \\
\hline Wielka Brytania & 278,8 & 4,0 \\
\hline Polska & 236,4 & 3,4 \\
\hline Wegry & 194,5 & 2,8 \\
\hline Czechy & 171,7 & 2,5 \\
\hline Stowacja & 157,5 & 2,3 \\
\hline Rosja & 152,1 & 2,2 \\
\hline Szwecja & 107,6 & 1,5 \\
\hline Holandia & 107,2 & 1,5 \\
\hline
\end{tabular}

Żród to: Yearbook... 2006.

T a be la VI. Ważniejsze narodowości turystów zagranicznych wykorzystujących bazę noclegową Bułgarii w $2003 \mathrm{r}$.

\begin{tabular}{|l|c|c|}
\hline \multicolumn{1}{|c|}{ Kraj } & $\begin{array}{c}\text { Wykorzystane } \\
\text { noclegi (w tys.) }\end{array}$ & $\begin{array}{c}\text { \% ogółu } \\
\text { wykorzystanych } \\
\text { noclegów }\end{array}$ \\
\hline Niemcy & 4173,3 & 45,6 \\
\hline Wielka Brytania & 1053,2 & 11,5 \\
\hline Rosja & 714,5 & 7,8 \\
\hline Szwecja & 404,0 & 4,4 \\
\hline Finlandia & 247,1 & 2,7 \\
\hline Izrael & 237,2 & 2,6 \\
\hline Belgia & 237,1 & 2,6 \\
\hline Dania & 209,9 & 2,3 \\
\hline Grecja & 115,9 & 1,3 \\
\hline Czechy & 103,6 & 1,1 \\
\hline Macedonia & 103,3 & 1,1 \\
\hline
\end{tabular}

Ż ródło: Yearbook... 2006.

Wpływy z zagranicznej turystyki przyjazdowej w wybranych krajach Europy Środkowej i Wschodniej przedstawia tab. VII. Największe wpływy posiada Chorwacja, Polska, Rosja, Czechy i Węgry. Bułgaria zajmuje szóstą pozycję, z wpływami 2,2 mld USD.

\section{WYDATKI NA WYJAZDY ZAGRANICZNE WEASNYCH OBYWATELI W KRAJACH REGIONU}

Wyjazdy zagraniczne Bułgarów ustabilizowały się na poziomie 3-4 mln podróży. Głównymi kierunkami wyjazdów są kraje sąsiednie: Turcja, Grecja i Macedonia (BACHVAROV 2006). Wydatki na podróże zagraniczne Bułgarów wyniosły w 2004 r.
$T \mathrm{ab} / \mathrm{e} \mathrm{V}$. The main nationalities of foreigners visiting Bulgaria in 2004

\begin{tabular}{|l|c|c|}
\hline \multicolumn{1}{|c|}{ Country } & Visitors ('000s) & $\begin{array}{c}\text { \% of the overall } \\
\text { number of visitors }\end{array}$ \\
\hline Macedonia & 857.9 & 12.3 \\
\hline Serbia with Montenegro & 853.1 & 12.2 \\
\hline Greece & 803.3 & 11.5 \\
\hline Turkey & 760.9 & 10.9 \\
\hline Germany & 719.8 & 10.3 \\
\hline Romania & 612.6 & 8.8 \\
\hline Great Britain & 278.8 & 4.0 \\
\hline Poland & 236.4 & 3.4 \\
\hline Hungary & 194.5 & 2.8 \\
\hline Czech Republic & 171.7 & 2.5 \\
\hline Slovakia & 157.5 & 2.3 \\
\hline Russia & 152.1 & 2.2 \\
\hline Sweden & 107.6 & 1.5 \\
\hline The Netherlands & 107.2 & 1.5 \\
\hline
\end{tabular}

So urce: Yearbook... 2006.

T a b I e VI. The main nationalities of foreign tourists staying in Bulgarian hotels in 2003

\begin{tabular}{|l|c|c|}
\hline \multicolumn{1}{|c|}{ Country } & $\begin{array}{c}\text { Accommodation } \\
\text { used ('000s) }\end{array}$ & $\begin{array}{c}\text { \% of all } \\
\text { accommodation } \\
\text { used }\end{array}$ \\
\hline Germany & 4173.3 & 45.6 \\
\hline Great Britain & 1053.2 & 11.5 \\
\hline Russia & 714.5 & 7.8 \\
\hline Sweden & 404.0 & 4.4 \\
\hline Finland & 247.1 & 2.7 \\
\hline Israel & 237.2 & 2.6 \\
\hline Belgium & 237.1 & 2.6 \\
\hline Denmark & 209.9 & 2.3 \\
\hline Greece & 115.9 & 1.3 \\
\hline Czech Republic & 103.6 & 1.1 \\
\hline Macedonia & 103.3 & 1.1 \\
\hline
\end{tabular}

So urce: Yearbook... 2006.

Income from foreign inward tourism in selected countries of Central and Eastern Europe is presented in table VII. The largest income is recorded in Croatia, Poland, Russia, the Czech Republic and Hungary with Bulgaria coming sixth at 2.2 billion US dollars.

\section{EXPENDITURE ON OUTWARD FOREIGN TOURISM IN THE REGION}

The number of foreign trips made by Bulgarians comes to 3-4 mln with the main directions of travel being to neighbouring countries: Turkey, Greece and Macedonia (BACHVAROV 2006). Expenditure on these 
$963 \mathrm{mln}$ USD (BARTOSZEWICZ, SKaLSKa 2006). Dla porównania, wydatki te w wybranych krajach omawianego regionu wyniosty (w mln USD): Białoruś - 524, Bośnia i Hercegowina - 126, Chorwacja - 850, Czechy - 2271, Estonia - 365, Litwa 637, Łotwa - 377, Macedonia - 55, Mołdawia 135, Polska - 3861, Rosja - 15 730, Rumunia 530, Słowacja - 745, Słowenia - 911, Ukraina 996, Węgry - 2864.

Wynika z tego, że Bułgaria jest szóstym krajem regionu pod względem łącznych wydatków na wyjazdy zagraniczne swoich obywateli. Warto ponadto zauważyć stosunkowo skromne wpływy $\mathrm{z}$ zagranicznej turystyki przyjazdowej w Rosji (tab. VII) i duże wydatki na wyjazdy zagraniczne swoich obywateli rysuje się duży deficyt finansowy tego kraju związany $\mathrm{z}$ turystyką zagraniczna.

T a b e I a VII. Wpływy z zagranicznej turystyki przyjazdowej w krajach Europy Srodkowej i Wschodniej w 2004 r. (w min USD)

\begin{tabular}{|l|c|}
\hline \multicolumn{1}{|c|}{ Kraj } & $\begin{array}{c}\text { Wpływy z zagranicznej } \\
\text { turystyki przyjazdowej }\end{array}$ \\
\hline Albania & 287 \\
\hline Białoruś & 490 \\
\hline Bośnia iHercegowina & 2168 \\
\hline Bułgaria & 6848 \\
\hline Chorwacja & \\
\hline Czarnogóra & 4169 \\
\hline Czechy & 806 \\
\hline Estonia & 778 \\
\hline Litwa & 267 \\
\hline Lotwa & 72 \\
\hline Macedonia & 95 \\
\hline Mołdawia & 5828 \\
\hline Polska & 5226 \\
\hline Rosja & 505 \\
\hline Rumunia & \\
\hline Serbia & 901 \\
\hline Słowacja & 1630 \\
\hline Słowenia & 1141 \\
\hline Ukraina & 4061 \\
\hline Wegry & \\
\hline
\end{tabular}

Ż r ó d ł o: BARTOSZEWICZ i SKALSKA, 2006, powołujacy się na materiały UNWTO.

\section{PODSUMOWANIE}

Bułgaria jest średniej wielkości krajem Europy Środkowej i Wschodniej o dużym potencjale turystycznym, w którym szczególną rolę odgrywaja walory wypoczynkowe wybrzeża czarnomorskiego. W ramach dawnego obozu krajów socjalistycznych Bułgaria była, obok Jugosławii, głównym ce- trips in 2004 reached $963 \mathrm{mln}$ dollars (BARTOSZEWICZ \& SKALSKA 2006). Here are the costs recorded in other selected countries of the region (in mlns of US dollars): Belarus 524, Bosnia \& Herzegovina - 126, Croatia 850, Czech Republic - 2271, Estonia - 365, Lithuania - 637, Latvia - 377, Macedonia 55, Moldavia - 135, Poland - 3861, Russia 15730, Romania - 530, Slovakia - 745 , Slovenia - 911, Ukraine - 996, Hungary 2864.

Bulgaria is the sixth country in the region as regards overall expenditure on foreign trips abroad made by its citizens. It is also worth noticing that in Russia the income from foreign inward tourism is relatively low (table VII), while expenditure on trips abroad made by its citizens is high suggesting a serious financial deficit.

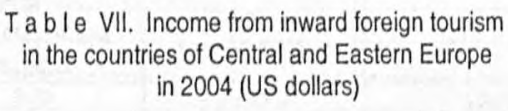

T a b le VII. Income from inward foreign tourism in the countries of Central and Eastern Europe in 2004 (US dollars)

\begin{tabular}{|l|c|}
\hline \multicolumn{1}{|c|}{ Country } & $\begin{array}{c}\text { Income from inward } \\
\text { foreign tourism }\end{array}$ \\
\hline Albania & \\
\hline Belarus & 287 \\
\hline Bosnia \& Herzegovina & 490 \\
\hline Bulgaria & 2168 \\
\hline Croatia & 6848 \\
\hline Czech Republic & 4169 \\
\hline Estonia & 806 \\
\hline Hungary & 4061 \\
\hline Latvia & 267 \\
\hline Lithuania & 778 \\
\hline Macedonia & 72 \\
\hline Moldavia & 95 \\
\hline Montenegro & \\
\hline Poland & 5828 \\
\hline Romania & 505 \\
\hline Russia & 5226 \\
\hline Serbia & \\
\hline Slovakia & 901 \\
\hline Slovenia & 1630 \\
\hline Ukraine & 1141 \\
\hline
\end{tabular}

S o u r c e: BARTOSZEWICZ \& SKALSKA, 2006 based on UNWTO materials.

\section{SUMMARY}

Bulgaria is a medium-size country in Central and Eastern Europe with a large tourism potential, and where the recreational assets of the Black Sea coast seem to play a particularly important role. In the former socialist bloc Bulgaria 
lem turystycznym regionu $\mathrm{w}$ urlopowej turystyce wypoczynkowej. Po wyraźnym kryzysie zagranicznej turystyki przyjazdowej do Bułgarii, związanym ze zmianami politycznymi, gospodarczymi i społecznymi w regionie na przełomie lat $80 \mathrm{i} 90$. ubiegłego wieku, Bułgaria stopniowo odzyskuje swoja pozycję na europejskim rynku turystycznym. Aktualnie zaliczyć ją można do pierwszej piątki krajów Europy Środkowej i Wschodniej o najbardziej rozwiniętej turystyce zagranicznej. Głównym regionem turystyki międzynarodowej w Bułgarii jest nadal wybrzeże Morza Czarnego, z którym wiąże się 75\% ogólnej liczby noclegów wykorzystywanych przez turystów zagranicznych i $50 \%$ noclegów wykorzystywanych w turystyce krajowej. Bułgaria jest również znaczącym źródłem turystyki zagranicznej, gdyż przeznacza na wyjazdy zagraniczne swoich obywateli blisko 1 mld USD rocznie. was, next to Yugoslavia, the main tourism destination as regards holiday tourism. After a clear crisis in foreign inward tourism in Bulgaria, resulting from the political, economic and social changes at the turn of the 1990s, the country is gradually recovering its position on the European tourism market. Currently it is among the top five most developed in Central and Eastern Europe. The main international tourism area is still the Black Sea coast with $75 \%$ of the overall number of nights and $50 \%$ of Bulgarian citizens. Bulgaria is also a significant source of outward foreign tourism, its citizens spending nearly one billion US dollars on trips abroad.

\section{BIBLIOGRAFIA - BIBLIOGRAPHY}

BACHVAROV, M., 2006, Tourism in Bulgaria, [w:] Tourism in the New Europe. The Challenges and Opportunities of EU Enlargement, D. Hall, M. Smith and B. Marciszewska (ed.), CAB International, 241-255.

BARTOSZEWICZ, W., SkAlSKA, T., 2006, Zagraniczna turystyka przyjazdowa do Polski w 2005 r., Instytut Turystyki, Warszawa.

Encyklopedia. Swiat i Polska. 2006, Wydawnictwo Naukowe PWN, Warszawa 2007.

International tourism attractions in Central and South-Eastern Europe (mapa pod red. P. Jordana), Österreichen Ost- und Südosteuropa-Institut, Wien 1999.
JORDAN, P. 1 in., 1999, International Tourism Attractions in Central and South-Eastern Europe (map), Österreichisches Ost- und Südosteuropa, Wien.

PIETRASZEWSKA, E., WYRZYKOWSKI, J., 1993, Touristic attractiveness of Central and Eastern Europe in the light of West European touristic guide-books and proposals of tourist agencie, [w:] Conditions of the Foreign Tourism Development in the Central and Eastern Europe, vol. 2, University of Wrocław Department of Regional and Tourism Geography, Wrocław.

Yearbook of Tourism Statistics. Data 2000-2004, 2006, WTO, Madrid.

WYRZYKOWSKI, J., 1995, Miejsce Polski na rynku turystycznym Europy Środkowej i Wschodniej, Turyzm 2. 